[Review Paper]

\title{
Product Selectivity in Alkane Conversion within Cavities of Enzymes and Zeolites: Influence of Cavity Volume on Product Selectivity
}

\author{
Akimitsu MIYAJI \\ Dept. of Environmental Chemistry and Engineering, Tokyo Institute of Technology, \\ 4259-G1-14, Nagatsuta-cho, Midori-ku, Yokohama 226-8502, JAPAN
}

(Received September 29, 2015)

\begin{abstract}
Alkane monooxygenases and proton-exchanged zeolites are catalysts that have cavities within their molecular structure and a catalytic site for $n$-alkane conversion in the cavity. The effect of the spatial volume of the cavity in the catalysts and the molecular volume of the reacting molecules on the product selectivity in catalytic reactions was evaluated by analysis of the product selectivity in the oxidation of $\mathrm{C}_{4}-\mathrm{C}_{8} n$-alkanes to alcohols by alkane monooxygenases, and in the cracking of $n$-pentane by proton-exchanged zeolites. The selectivity for production of the 2-hydroxyalkane enantiomer from $n$-alkanes depended on the cavity volume of the substrate binding site in the alkane monooxygenases. Further, the selectivity for ethane and propene in $n$-pentane cracking by protonexchanged zeolite also depended on the cavity volume of the zeolite. From these dependencies, we propose that product selectivity is expressed if the molecular volume of the reacting molecules or reaction intermediates is almost identical to the volume of the cavity in which the catalytic reactions proceed.
\end{abstract}

\section{Keywords}

Alkane monooxygenase, Zeolite, Cavity, Product selectivity, Alkane conversion

\section{Introduction}

Natural resources are the basis of many industries that are essential to convenient and comfortable modern life. However, despite the abundance of natural resources, there are inherent limitations, especially in the case of non-renewable resources. Sustainable use of these resources require efficient processes that selectively produce useful raw materials from natural resources. In particular, catalysts that express high product selectivity are important for such processes.

Product selectivity in catalytic reactions is achieved by specific orientation of the reacting molecule relative to the catalytic site. In other words, the catalyst should have the characteristic of molecular recognition. Regio- and enantio-selectivity for butanol isomers in the oxidation of $n$-butane (Fig. 1) is here considered as an example. Butanol has two regioisomers, 1-butanol and 2-butanol. Furthermore, 2-butanol contains a chiral carbon resulting in two enantiomers, the $R$-form and the $S$-form. To obtain a specific butanol regioisomer, an oxygen atom must be inserted into one of the carbonhydrogen bonds at a specific carbon in $n$-butane. Therefore, to produce a specific butanol regioisomer, this specific carbon must be positioned close to the cat-

DOI: dx.doi.org/10.1627/jpi.59.35

*E-mail: akimiyaji@chemenv.titech.ac.jp alytic site as the $n$-butane molecule approaches the catalytic site. For instance, the C-2 and C-3 positions of $n$-butane should be close to the catalytic site for selective production of 2-butanol from $n$-butane. Moreover, to generate one enantiomer of 2-butanol, an oxygen atom must be inserted into a specific carbon-hydrogen bond at the C-2 and C-3 positions of $n$-butane. Therefore, this specific carbon-hydrogen bond should be oriented toward the catalytic site as the $n$-butane molecule approaches the catalytic site. For example, to selectively obtain $(R)$-2-butanol from $n$-butane, the pro- $R$ hydrogen bonded to the $\mathrm{C}-2$ and $\mathrm{C}-3$ positions of $n$-butane should be positioned close to the catalytic site. To achieve such specific orientation of the carbonhydrogen bond toward the catalytic sites, the catalyst must recognize the orientation of the $n$-butane molecule.

Recognition of molecular orientation is based on the intermolecular forces between the two molecules, i.e., the recognizing molecule and the recognized molecule. In the case of catalysts, the reacting molecule is recognized by the molecular characteristics of the surface of the catalytic site. If the surfaces around the catalytic site and the reacting molecule have functional groups generating strong intermolecular forces, the catalyst can recognize the orientation of the reacting molecule via a few intermolecular forces, and can selectively convert the reacting molecule to a specific product. In con- 


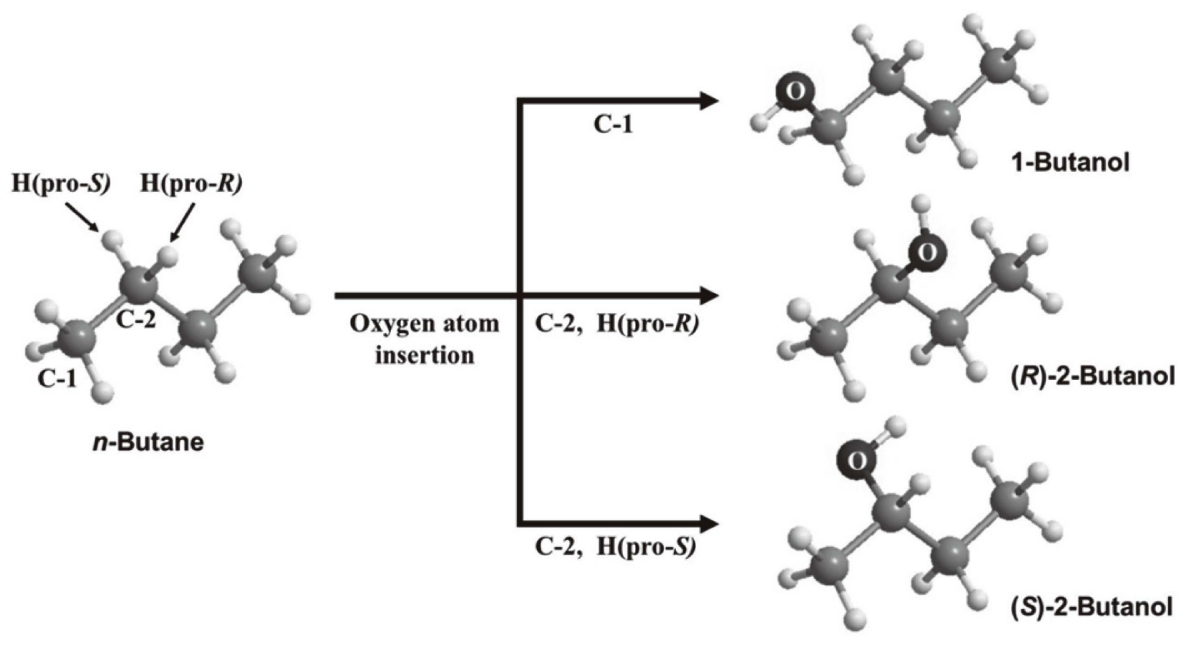

Fig. 1 Butanol Regioisomers and Enantiomers Produced in $n$-Butane Oxidation

trast, if the surface around the catalytic site and/or the reacting molecule possesses functional groups which generate very weak intermolecular forces, recognition of a reacting molecule by the catalyst is difficult to achieve. For instance, alkanes contain only carboncarbon bonds and carbon-hydrogen bonds, so only weak intermolecular forces such as van der Waals forces are operative. To achieve selective conversion of a reacting molecule with weak intermolecular forces to a particular product, the intermolecular forces generated by the catalyst must act effectively.

A capsule-like supramolecule contain a cavity expressing molecular recognition ability ${ }^{1)}$. Within the cavity, weak intermolecular interactions with alkane molecules can operate effectively. The molecular recognition ability is correlated with the cavity volume of the capsule-like molecule. High molecular recognition tends to occur if the molecular volume of the guest molecule matches the spatial cavity volume of the host molecule ${ }^{2}$. In other words, the intermolecular forces between the cavity surface of the host molecule and the guest molecule operate most effectively if the guest molecule occupies the cavity of the host molecule. This tendency implies that the molecular recognition ability can be controlled by the cavity volume of the host molecule, and the product selectivity in the catalytic reaction can be controlled by the cavity volume if the catalytic site is located within the cavity. Enzymes and zeolites are both types of catalysts that contain a cavity in their molecular structure, and their catalytic sites are located in the cavity. Therefore, the product selectivities of these catalysts in catalytic reactions may be influenced by the cavity volume of the catalysts and the molecular volume of the reacting molecules.

The present study tried to clarify the effect of the volumes of the cavity and of the reacting molecules on the product selectivity in catalytic reactions. To include only weak intermolecular forces acting on the reacting molecules, short chain $n$-alkanes were used as the reacting molecules.

\section{Regio- and Enantio-selectivities for Alcohol Isomers Produced from $\boldsymbol{n}$-Alkane by Alkane Monooxygenase}

Alkane monooxygenase is an enzyme that produces alcohols selectively from $n$-alkanes at room temperature under atmospheric pressure ${ }^{3)}$. The several types of alkane monooxygenases have different protein structures of the enzymes (Fig. 2) and different metal cofactors that bind to the enzyme in the catalytic site (Fig. 3). On the other hand, these enzymes share the common feature of a cavity capable of enclosing the reacting molecules (substrate binding site) as shown in Fig. 3. The shapes and cavity volumes of the substrate binding sites are different for each enzyme.

The concept that the cavity volume governs the recognition of a host molecule is particularly true for apolar binding processes, not only within a synthetic molecular capsule but also, in some cases, within an enzyme environment ${ }^{4}$. Thus, if alkane recognition by these enzymes is determined by the cavity volume, the selectivity for the regioisomer and enantiomer of the alcohols produced from $n$-alkanes should depend on the molecular volume of the $n$-alkane and the cavity volume of the substrate binding site in those enzymes. Therefore, our research has focused on evaluating the selectivity for alcohol isomers in the oxidation of $n$-alkane by copper-containing alkane monooxygenases. We previously reported $n$-alkane oxidation to alcohol by copper-containing methane monooxygenase (particulate methane monooxygenase: $\mathrm{pMMO})^{5)}$ and ammonia monooxygenase ${ }^{6}$. 
(A)

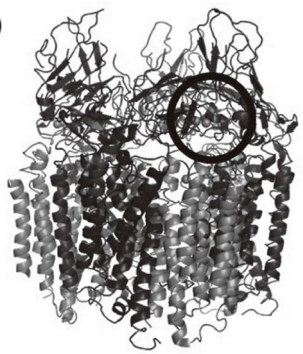

(B)

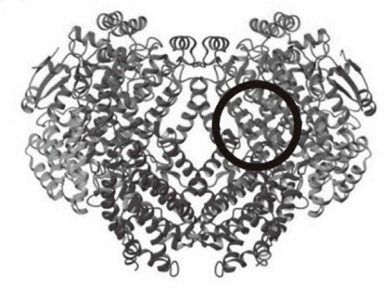

(C)

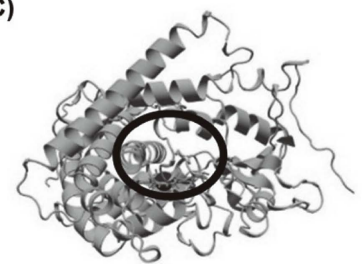

tion proceed with retention of the configuration for $n$-alkanes ${ }^{13)}$.

Methylosinus trichosporium OB3b and Methylococcus capsulatus (Bath) expressing pMMO (pMMO-Mt and pMMO-Mc, respectively) were prepared in accordance with previously reported methods ${ }^{14)} \cdot n$-Alkane oxidation reactions were carried out in $50 \mathrm{mM}(1 \mathrm{M}=1 \mathrm{~mol}$ $\mathrm{L}^{-1}$ ) phosphate buffer ( $\mathrm{pH}$ 7.0) containing $1 \mathrm{mM}$ duroquinol at $30{ }^{\circ} \mathrm{C}$ under atmospheric pressure. The products were extracted from the reaction mixture using dichloromethane and analyzed by gas chromatography (GC). The amounts of the products were determined by GC analysis using a TC-WAX column $(30 \mathrm{~m} \times$ $0.25 \mathrm{~mm}$ i.d., $0.25 \mu \mathrm{m}$ film thickness, GL Science) and a flame ionization detector. Furthermore, the 2-alcohol enantiomers were derivatized to the corresponding esters with trifluoroacetate and the enantioselectivities were determined by GC analysis using a Chiraldex G-TA column $(20 \mathrm{~m} \times 0.25 \mathrm{~mm}$ i.d., $0.12 \mu \mathrm{m}$ film thickness, Sigma-Aldrich) and a flame ionization detector.

Oxidation of $n$-butane by pMMO-Mc and pMMO-Mt produced only 2-butanol, and oxidation of $n$-pentane produced only 2-pentanol. These results indicate that the pMMO-Mc and pMMO-Mt selectively produce 2 -hydroxyalkanes from $n$-butane and $n$-pentane. The regioselectivity indicates that the second carbons from the terminal of $n$-butane and $n$-pentane carbon chains is positioned close to the catalytic site during oxidation at the catalytic sites of pMMO-Mc and pMMO-Mt.

The $R$-forms were the major enantiomers of the 2 -hydroxyalkanes produced from $n$-butane and $n$ pentane (Table 1); $75 \%$ of 2-butanol and $86 \%$ of 2 -pentanol were produced as $R$-form enantiomers. Thus, $(R)$-2-hydroxyalkanes were selectively produced from $n$-butane and $n$-pentane by pMMO-Mc and pMMO-Mt. The enantioselectivity indicates that the pro- $R$ hydrogen at the second carbons from the terminal of $n$-butane and $n$-pentane carbon chains is positioned close to the catalytic site as shown in Fig. 5. From the view point of molecular recognition, these monooxygenases can discriminate the pro- $R$ hydrogen at the second carbons from the terminal of $n$-butane and $n$ pentane carbon chains.

According to prior reports ${ }^{15)}$ and our previous study), pMMO-Mc and pMMO-Mt have the same substrate range and product selectivities, suggesting that the two pMMOs have similar protein structures around the catalytic site which are involved in the recognition of $n$-butane and $n$-pentane. However, the amino acid sequences and the crystal structures of pMMO-Mc and pMMO-Mt show some structural differences between the active sites (Fig. 4), although the overall shapes of the proteins are almost identical ${ }^{16}$. Therefore, the amino acid residues in the active site that control the orientation of $n$-butane and $n$-pentane are possibly conserved in the two pMMOs, and differences in the local 
(I)

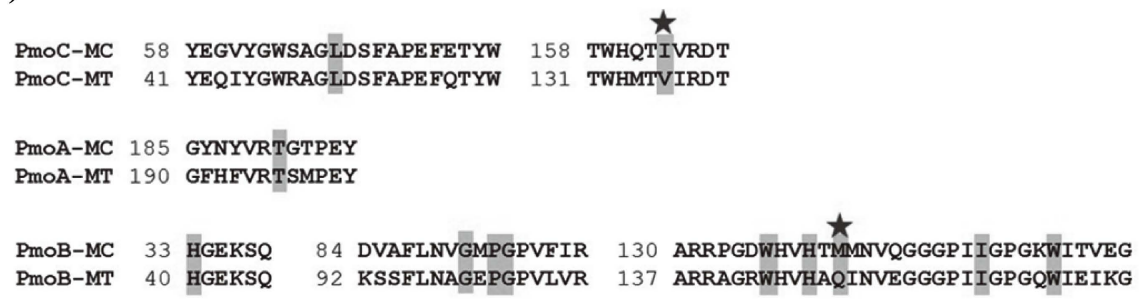

(II)
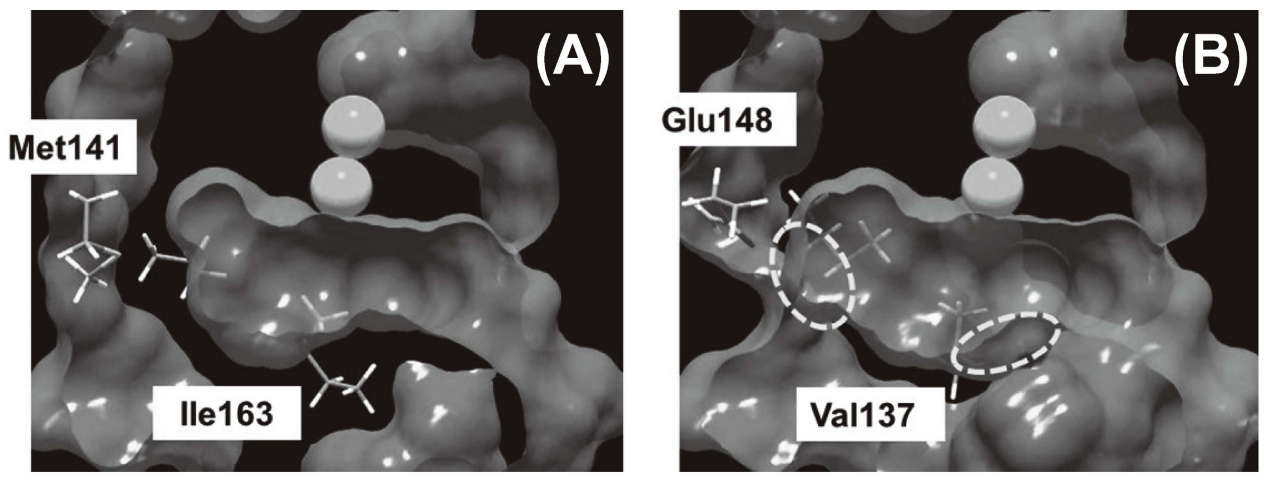

(I) Alignment of amino acid sequences of pMMO-Mc and pMMO-Mt. Amino acid residues forming the surface of the cavity are shaded; amino acid residues differing between the two enzymes are indicated by star symbols. (II) Protein structure of pMMO-Mc (PDB: 3RGB) (A) and homology model structure of pMMO-Mt (B). Copper ions are shown as balls, different amino acid residues of pMMO-Mc and pMMO-Mt are shown as sticks, and the Connolly surface of the protein is shown in gray. The right side of the cavity opens up to the outside of the protein molecule.

Fig. 4 Cavity Structures of pMMO-Mc and pMMO-Mt

Table 1 Selectivity for 2-Hydroxyalkane Enantiomers in $n$-Butane and $n$-Pentane Oxidation with pMMO-Mt and pMMO-Mc

\begin{tabular}{|c|c|c|c|c|}
\hline \multirow{2}{*}{ Biocatalyst } & \multirow{2}{*}{$\begin{array}{l}\text { Amount of 2-hydroxyalkane }{ }^{\text {a) }} \\
{\left[\mu \mathrm{mol} \mathrm{g-wet} \mathrm{cells}{ }^{-1}\right]}\end{array}$} & \multicolumn{2}{|c|}{ Distribution of 2-hydroxyalkane enantiomers [\%] } & \multirow{2}{*}{ e.e. ${ }^{c)}[\%]$} \\
\hline & & $R$-form & $S$-form & \\
\hline \multicolumn{5}{|c|}{$n$-Butane oxidation ${ }^{\mathrm{b})}$} \\
\hline pMMO-Mt & 6.8 & 76 & 24 & $52(R)$ \\
\hline pMMO-Mc & 7.9 & 75 & 25 & $50(R)$ \\
\hline \multicolumn{5}{|c|}{$n$-Pentane oxidation ${ }^{\text {b) }}$} \\
\hline pMMO-Mt & 3.4 & 86 & 14 & $72(R)$ \\
\hline pMMO-Mc & 8.1 & 86 & 14 & $72(R)$ \\
\hline
\end{tabular}

a) Amount of 2-hydroxyalkane produced over a reaction time of $10 \mathrm{~min}$.

b) Reactions were carried out in at least triplicate at $30{ }^{\circ} \mathrm{C}$ in $50 \mathrm{mM}$ phosphate buffer (pH 7.0) containing $1.2 \mathrm{mM}$ duroquinol, $4.5 \mathrm{~g}$-wet cells $\mathrm{L}^{-1}$ whole cells, and $n$-butane or $n$-pentane. Initial concentrations of $n$-butane and $n$-pentane dissolved in the reaction mixture were $230 \mu \mathrm{M}$ and $92 \mu \mathrm{M}$, respectively. The data are shown as the average of separate reactions.

c) Defined as $|R-S| /(R+S) \times 100$, where $R$ and $S$ are the amounts of each enantiomer. The major enantiomer is shown in parentheses.

structures of the active site do not affect the orientation of $n$-butane and $n$-pentane.

As shown in Table 1, the selectivity of the two pMMOs for $(R)$-2-hydroxyalkanes increased with increased $n$-alkane chain length from four to five. The enhanced enantioselectivity for the $(R)$-2-hydroxyalkanes means that the ability of the two pMMOs to recognize the orientation of the $\mathrm{C}-\mathrm{H}$ bond at the second carbons from the terminal of $n$-alkane carbon chains gradually changed as the molecular size increased. The cavity volume of the substrate binding site in pMMO is about $0.14 \mathrm{~nm}^{3} . \quad n$-Hexane was not oxidized by pMMO, indicating that the cavity volume cannot accommodate the $n$-hexane molecule $\left(0.113 \mathrm{~nm}^{3}\right)$. Therefore, a $n$ pentane molecule $\left(0.096 \mathrm{~nm}^{3}\right)$ spatially fills the cavity. The increase in enantioselectivity with higher carbon number from four to five suggests that the cavity volume of the substrate binding site in pMMO determines 


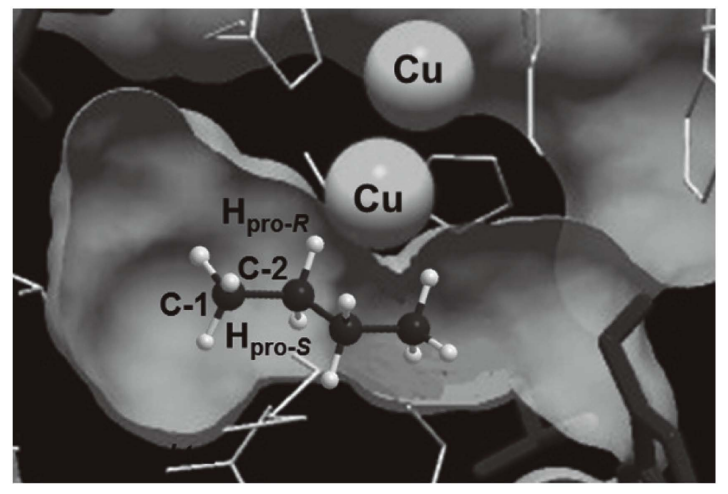

Fig. 5 Orientation of $n$-Butane in the Cavity of pMMO

the position of second carbons from the terminal of $n$ alkane carbon chains, and the orientation of the $\mathrm{C}-\mathrm{H}$ bond at the second carbons of $n$-alkanes relative to the catalytic site.

\section{2. Ammonia Monooxygenase}

Ammonia monooxygenase from Nitrosomonas europaea (AMO-Ne) is a protein member of the pMMO-Mc and pMMO-Mt family. AMO-Ne is involved in the physiological oxidation of ammonia to hydroxylamine ${ }^{17)}$, which is different from the physiological activity of pMMO, but can oxidize some $n$-alkanes (including methane as non-growth substrates) to the corresponding alcohols ${ }^{18)}$. AMO-Ne has a larger substrate range than the two pMMOs ${ }^{18), 19)}$ as well as different selectivity for the regioisomers of alcohols produced from alkanes ${ }^{18)}$, and for the enantiomers of epoxides produced from alkenes ${ }^{20)}$. These results suggest that the substrate binding site of AMO-Ne has a spatially larger cavity and a different surface structure compared to the two pMMOs.

The structural differences between AMO-Ne and the two pMMOs could not be clarified because the crystal structure of AMO-Ne has not been elucidated. On the other hand, the high amino acid sequence homology between AMO-Ne and the two pMMOs (approximately $40 \%$ identity and $65 \%$ similarity ${ }^{21)}$ suggests that these enzymes are evolutionarily related, and indicates that the tertiary and quaternary protein structures of these enzymes have high similarity. In addition, AMO-Ne contains copper ions like pMMO. The amino acid residues forming the copper binding sites in the two pMMOs are well-conserved in AMO-Ne, which suggests that the catalytic site of AMO-Ne is also a di-copper site as in the two pMMOs. Based on the high homology, we constructed a homology protein structure model of the substrate binding cavity in AMO-Ne based on the protein structure of $\mathrm{pMMO}-\mathrm{Mc}^{6}$.

The model structure of AMO-Ne is shown in Fig. 6. According to the model structure, the shape and cavity volume of the substrate binding site differ from that of pMMO. The cavity of the substrate binding site in
AMO-Ne can accommodate $n$-octane $\left(0.147 \mathrm{~nm}^{3}\right)$, but not $n$-nonane $\left(0.164 \mathrm{~nm}^{3}\right)^{22)}$. The cavity of pMMOMc has two pockets around the bottom, indicated as Pkt-1 and Pkt-2 in Fig. 6(A). The spatial volume of $\boldsymbol{P k t - 2}$ is larger than that of Pkt-1. Substitution of an isoleucine residue for an alanine residue increases the volume of $\boldsymbol{P k t} \mathbf{1}$ because of the difference in the van der Waals volumes of the isoleucine residue and alanine residue $\left(0.165 \mathrm{~nm}^{3} \text { and } 0.090 \mathrm{~nm}^{3} \text {, respectively }\right)^{23}$. Furthermore, substitution of a tryptophan residue for a histidine residue widens the entrance of the cavity. These structural changes are consistent with the differences in the substrate range of pMMO-Mc relative to that of AMO-Ne; AMO-Ne can oxidize larger substrates (such as aromatics) than pMMO-Mc, indicating that the homology model of AMO-Ne has a valid protein structure.

The differences in the local structure of these enzymes may also affect their ability to discriminate between the prochiral $\mathrm{C}-\mathrm{H}$ bonds at second carbons from the terminal of $n$-alkane carbon chains, which enables the enzyme to selectively generate a specific enantiomer of 2-hydroxyalkanes. Thus, we examined the selectivity of AMO-Ne for alcohol regioisomers and enantiomers in $n$-alkane oxidation. AMO-Ne was prepared in accordance with previously reported methods $^{6), 24)}$, and the oxidation of alkanes by AMO-Ne was performed as for $\mathrm{pMMO}$.

Oxidation of $\mathrm{C}_{4}-\mathrm{C}_{8} n$-alkanes formed only 1- and 2-hydroxyalkanes. As shown in Table 2, the distribution of 1- and 2-hydroxyalkanes is dependent on the specific $n$-alkane, as reported previously ${ }^{20)}$. Both 1-butanol and 2-butanol were produced from the oxidation of $n$-butane by AMO-Ne in whole cells. In the initial stage of $n$-butane oxidation, $82 \%$ of the product was 2-butanol; the distribution of butanol regioisomers was almost constant during the reaction. Thus, AMO$\mathrm{Ne}$ in whole cells produces 2-butanol selectively from $n$-butane. In other words, $n$-butane oxidation proceeds predominantly when the $\mathrm{C}-2$ and $\mathrm{C}-3$ positions of $n$ butane are located close to the catalytic site of AMONe. On the other hand, both 1-pentanol and 2-pentanol were produced in the oxidation of $n$-pentane by AMO$\mathrm{Ne}$, indicating that the oxidation reaction proceeded at the C-1, C-2, C-4, and C-5 positions of $n$-pentane. The major product of $n$-pentane oxidation was 1 -pentanol; the selectivity for 1 -pentanol was $74 \%$, and remained constant during the reaction. This regioselectivity indicates that oxidation of $n$-pentane proceeds predominantly when the $\mathrm{C}-1$ and C-5 positions of $n$-pentane are located close to the catalytic site of AMO-Ne. 1-Hydroxyalkane was also the major product in the oxidation of $n$-hexane to hexanol; the selectivity for 1-hexanol was $74 \%$. However, 1-heptanol and 2-heptanol were produced in almost the same ratio in the oxidation of $n$-heptane. This regioselectivity indi- 
(I)

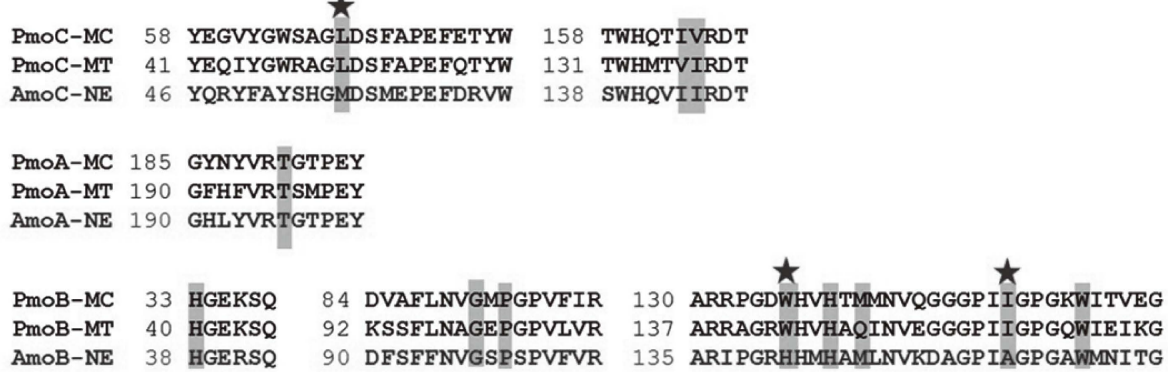

(II)
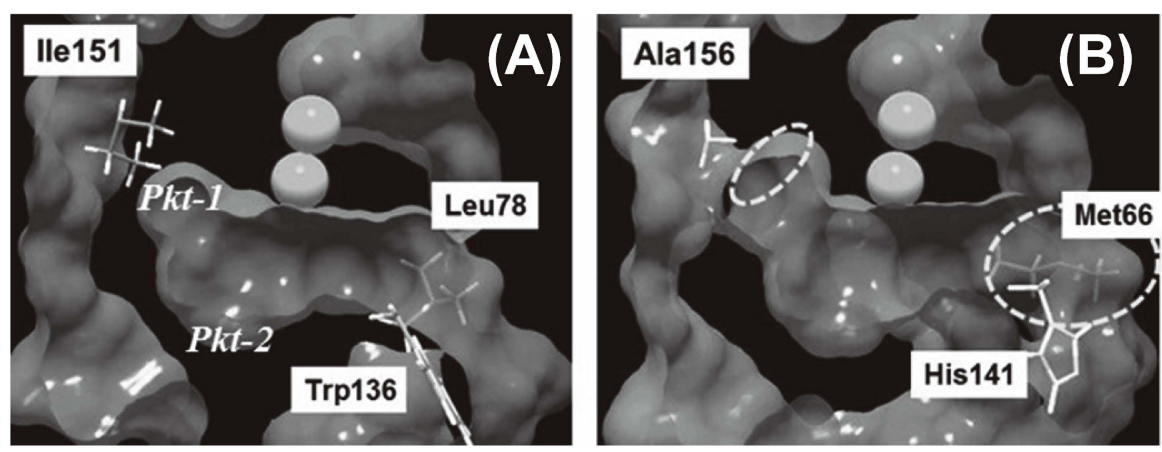

(I) Alignment of amino acid sequences of pMMO-Mc, pMMO-Mt and AMO-Ne. Amino acid residues forming the surface of the cavity are shaded, and amino acid residues differing between pMMO-Mc or pMMO-Mt, and AMO-Ne are indicated by star symbols.

(II) Protein structure of pMMO-Mc (PDB: 3RGB) (A) and homology model structure of AMO-Ne (B). Copper ions are shown as balls, different amino acid residues of pMMO-Mc and AMO-Ne are shown as sticks, and the Connolly surface of the protein is shown in gray. The right side of the cavity opens up to the outside of the protein molecule.

Fig. 6 Protein Surface Structure of the Cavity Adjacent to the Di-nuclear Copper Center of pMMO-Mc and $\mathrm{AMO}-\mathrm{Ne}$

Table $2 n$-Alkane Oxidation by AMO-Ne ${ }^{\text {a) }}$

\begin{tabular}{|c|c|c|c|c|c|c|}
\hline \multirow{2}{*}{ Substrate $^{\mathrm{b})}$} & \multirow{2}{*}{$\begin{array}{l}\text { Amount of alcohols }{ }^{\mathrm{c})} \\
{\left[\mu \mathrm{mol} \text { g-wet cells }{ }^{-1}\right]}\end{array}$} & \multicolumn{2}{|c|}{ Distribution of alcohol regioisomers [\%] } & \multicolumn{2}{|c|}{$\begin{array}{c}\text { Distribution of 2-hydroxyalkane } \\
\text { enantiomers [\%] }\end{array}$} & \multirow{2}{*}{ e.e. $^{\mathrm{d})}[\%]$} \\
\hline & & 1-hydroxyalkane & 2-hydroxyalkane & $R$-form & $S$-form & \\
\hline$n-\mathrm{C}_{4} \mathrm{H}_{10}$ & 16.5 & 18 & 82 & 23 & 77 & $54(S)$ \\
\hline$n-\mathrm{C}_{5} \mathrm{H}_{12}$ & 12.7 & 74 & 26 & 38 & 62 & $24(S)$ \\
\hline$n-\mathrm{C}_{6} \mathrm{H}_{14}$ & 13.6 & 73 & 27 & 72 & 28 & $44(R)$ \\
\hline
\end{tabular}

a) Reactions were carried out in at least triplicate at $30{ }^{\circ} \mathrm{C}$ in $50 \mathrm{mM}$ phosphate buffer $(\mathrm{pH} 7.0)$ containing $1.2 \mathrm{mM}$ duroquinol, $4.5 \mathrm{~g}$-wet cells $\mathrm{L}^{-1}$ whole cells, and $n$-alkane. Data are presented as the average of three separate reactions.

b) Initial concentrations of substrates dissolved in the reaction mixture were: $\left[n-\mathrm{C}_{4} \mathrm{H}_{10}\right]=230 \mu \mathrm{M} ;\left[n-\mathrm{C}_{5} \mathrm{H}_{12}\right]=92 \mu \mathrm{M} ;\left[n-\mathrm{C}_{6} \mathrm{H}_{14}\right]=$ $60 \mu \mathrm{M} ;\left[n-\mathrm{C}_{7} \mathrm{H}_{16}\right]=38 \mu \mathrm{M} ;\left[n-\mathrm{C}_{8} \mathrm{H}_{18}\right]=31 \mu \mathrm{M}$.

c) Amount of 2-hydroxyalkane produced over a reaction time of $10 \mathrm{~min}$.

d) Defined as $|R-S| /(R+S) \times 100$, where $R$ and $S$ are the amounts of each enantiomer. The major enantiomer is shown in parentheses.

cates that the position of the carbon atom of the $n$ alkane molecule relative to the catalytic site is strongly influenced by the chain length of the $n$-alkane. In the oxidation of $n$-alkane with manganese porphyrin, the position of oxidation could be changed by introducing bulky groups around the Mn center ${ }^{25)}$. Therefore, the steric hindrance caused by the amino acid residues around the catalytic site presumably affects the position of the $n$-alkane relative to the catalytic site.

Either enantiomer may predominate in the 2-hydroxyalkanes generated from $\mathrm{C}_{4}-\mathrm{C}_{7} n$-alkanes. For instance, $77 \%$ of 2-butanol produced was the $S$-enantiomer, as shown in Table 2. Thus, AMO-Ne shows some selectivity for $(S)$-2-butanol in $n$-butane 
oxidation. Such selectivity indicates that the pro- $S$ hydrogen at the C-2 and C-3 positions of $n$-butane is preferably oriented toward the catalytic site within AMO-Ne. Furthermore, $62 \%$ of the 2-pentanol produced was the $S$-enantiomer, which is consistent with the trend observed in $n$-butane oxidation. Thus, AMO$\mathrm{Ne}$ can also recognize the pro- $S$ hydrogen at the C-2 and C-4 positions of $n$-pentane, although the selectivity is lower than that for $n$-butane. The enantioselectivity for $(R)$-2-hydroxyalkanes increased as the chain length of the $n$-alkanes increased from four to seven, consistent with the increase in the enantioselectivities of the two pMMOs for $(R)$-2-hydroxyalkanes as the $n$-alkane chain length increased from four to five, as discussed in section 2. 2. (see Table 1). The increased enantioselectivity for $(R)$-2-hydroxyalkane indicates that recognition of the orientation of the $\mathrm{C}-\mathrm{H}$ bond at second carbons from the terminal of $n$-alkane carbon chains gradually changed with higher molecular size. The cavity volume of the substrate binding site in AMO-Ne may determine the orientation of the $\mathrm{C}-\mathrm{H}$ bond of $n$ alkanes relative to the catalytic site. However, essentially racemic 2 -octanol was produced from $n$-octane (Table 2). These distributions indicate that the ability of AMO-Ne to discriminate between the prochiral hydrogens at second carbons from the terminal of $n$ alkanes varies according to the chain length.

\section{3. Effect of Cavity Volume of Substrate Binding Site on the Selectivity for 2 -Hydroxyalkane} Stereoisomer

To evaluate the influence of the cavity volume on the selectivity for alcohol enantiomers, the selectivities of the copper-containing monooxygenases were plotted against the ratio of the volume of the reacting $n$-alkane molecule to the volume of the cavity in the enzyme ( $n$ alkane/cavity ratio). As mentioned in Section 2. 2., the selectivities for the alcohol regioisomers were not correlated with the $n$-alkane/cavity ratio. On the other hand, the selectivities for the 2-hydroxyalkane enantiomer were correlated with the $n$-alkane/cavity ratio as shown in Fig. 7. Higher $n$-alkane/cavity ratio of about 0.6 resulted in high selectivity for either enantiomer. In other words, the $n$-alkane molecule was recognized at the substrate binding site of the enzyme. On the other hand, selectivity for the 2-hydroxyalkane enantiomers was low if the volume of the $n$-alkane molecule was sufficiently smaller than the cavity volume. In other words, the $n$-alkane recognition ability of the enzyme substrate binding site was low. Under the conditions of $n$-alkane/cavity ratio greater than 0.6 , pMMO expressed higher selectivity whereas AMO-Ne showed almost no selectivity.

This tendency could also be observed in the preliminary analysis of $n$-alkane oxidation by iron-containing methane monooxygenase (sMMO). The sMMOpromoted oxidation proceeded at the di-nuclear iron

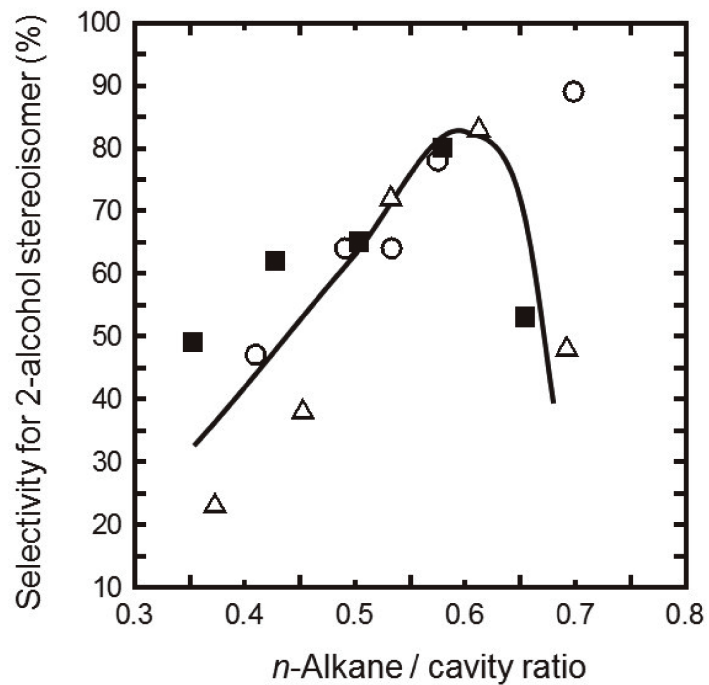

$n$-Alkane/cavity ratio is calculated by dividing the molecular volume of $n$-alkane with the spatial volume of cavity in the enzyme. $\bigcirc$ : selectivity of pMMO-Mc and pMMO-Mt for $R$-form 2-hydroxyalkane; $\triangle$ : selectivity of AMO-Ne for $R$-form 2-hydroxyalkane; $\square$ : selectivity of sMMO for $S$-form 2-hydroxyalkane.

Fig. 7 Effect of the Volume of the Substrate Binding Cavity of the Alkane Monooxygenase on the Selectivity for 2-Hydroxyalkane Enantiomer from $n$-Alkane

center in the hydroxylase component. The cavity of the substrate binding site is adjacent to the di-iron center based on a crystallographic study of sMMO with alcohol ${ }^{26)}$. The cavity has a volume of $0.185-0.225 \mathrm{~nm}^{3}$, which is adequate to accommodate the non-growth substrates of sMMO, such as $\mathrm{C}_{2}-\mathrm{C}_{8} n$-alkanes ${ }^{26), 27)}$; $n$ alkane oxidation proceeded in the cavity. The distribution of the $S$-form enantiomer of 2-hydroxyalkane increased with higher carbon-number of the reacting $n$ alkane from four to seven. The enhanced enantioselectivity for the $(S)$-2-hydroxyalkane indicates that recognition of the orientation of the $\mathrm{C}-\mathrm{H}$ bond at second carbons from the terminal of $n$-alkane carbon chains gradually changed with larger molecular size. Low selectivity for the 2-octanol enantiomer from $n$ octane indicates absence of molecular recognition. The reduced molecular recognition is probably due to the change in the protein structure of the enzyme, as the volume of the reacting molecule is almost the same as that of the enzyme cavity.

Based on a study of a synthetic molecular capsule, the orientation of the $n$-alkane inside the capsule is recognized if the $n$-alkane "fits" into the cavity of the capsule like a fluid ${ }^{2}$. The surface inside the molecular capsule interacts with the carbon-hydrogen bonds of the $n$-alkane via weak intermolecular forces, causing the capsule to recognize the $n$-alkane molecule. The recognition mechanism of the $n$-alkane in the small space of the cavity may be distinct from the "induced- 


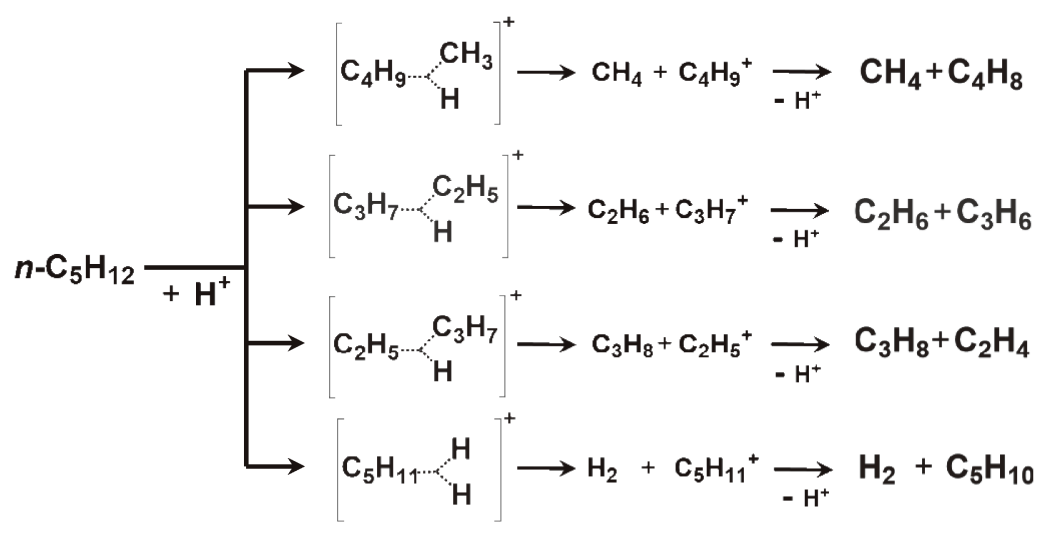

Fig. 8 Carbonium Ion Intermediates in the $n$-Pentane Unimolecular Decomposition Reaction

fit" model $^{28)}$ used to explain the enzymatic recognition mechanism in previous studies.

\section{Effect of Zeolite Pore Cavity Volume on Product Selectivity in Alkane Conversion}

Section 2. demonstrated that the cavity volume of the substrate binding site in the enzyme adjacent to the catalytic site is a key molecular structural factor for expressing the selectivity for alcohol enantiomers generated from $n$-alkanes. The cavity volume is a geometrical factor. Thus, if the cavity volume is important for the expression of product selectivity, expression of such volume-dependent product selectivity would not be limited to enzymes. Thus, we examined the effect of cavity volume on product selectivity in alkane cracking by zeolites.

The cracking of alkanes by solid acid catalysts, such as proton-exchanged zeolites, proceeds via two mechanisms: one involving a carbenium ion species (Mechanism-1), and the other based on the formation of pentacoordinated carbonium ions (Mechanism-2) ${ }^{29)}$. In Mechanism-1, the hydride transfer reaction becomes significant in alkane activation at high conversion, and alkenes accumulate in the system. In Mechanism-2, the reaction proceeds through protonation (protolysis) of the covalent $\mathrm{C}-\mathrm{C}$ single bond, whereas protolysis of the $\mathrm{C}-\mathrm{H}$ bond leads to pentacoordinated carbonium ion intermediates, with subsequent production of hydrogen and concomitant formation of trivalent carbenium ions. Thus, direct $\mathrm{C}-\mathrm{C}$ and $\mathrm{C}-\mathrm{H}$ bond cleavage are the initial processes of the cracking reactions of lower alkanes. For example, in the conversion of $n$-pentane under low pressure, the primary reactions to generate methane, ethane, propane, and hydrogen, along with butyl, propyl, ethyl, and pentyl carbenium ions, involve activation of $n$-pentane via carbonium ion intermediates, as expressed by reactions (1)-(4) in Fig. 8.

To investigate the dependence of the catalytic performance on the pore structure of the zeolite, conversion of $n$-pentane was carried out using various zeolites at $823 \mathrm{~K}$ with $10.1 \mathrm{kPa}$ of $n$-pentane ${ }^{30)}$. Various zeolites with 10- and 12-membered rings (Table 3) were hydrothermally synthesized using various structuredirecting agents ${ }^{30)}$, and used as catalysts. The product selectivities were examined over a wide range of conversion values from zero to about $90 \%$. The catalytic activity and product selectivity strongly depended on the type of zeolite, and the product selectivities over various zeolites depended on the $n$-pentane conversion. However, the primary reactions for all zeolites presumably proceeded via Mechanism-2. Therefore, by extrapolating the selectivity versus conversion curves to zero conversion, the primary products were identified as methane, ethane, propane, ethene, propene, butenes, pentenes, and hydrogen for all zeolites examined. The selectivities for the produced hydrocarbons are expressed as the number of moles of product formed per 100 moles of $n$-pentane converted. The selectivity ratio of alkenes to alkanes and hydrogen over each zeolite was almost equal to 1.3-1.5; these values are larger than 1.0, suggesting that the alkenes formed by the primary reactions as described by reactions (1)-(4) in Fig. 8, are further converted to other alkenes.

To examine the effect of the zeolite cavity volume on the selectivity for the primary products, the selectivities for pairs of alkanes or hydrogen and alkene were plotted against the cavity volume. We defined $D_{\mathrm{i}}(\mathrm{nm})$ as the diameter of the largest sphere that can be included in the zeolite framework; the spatial volume of the zeolite cavity was estimated from the formula (4/3) $\pi\left(D_{\mathrm{i}} / 2\right)^{3}$. The shape of a zeolite cavity is zeolitedependent. The largest sphere that can be accommodated in the zeolite framework was reported previous$1 y^{31), 32)}$.

The selectivities for reactions (1)-(4) in Fig. 8 were influenced by the cavity volume of the zeolite. The selectivities were almost constant for a zeolite cavity with a large spatial volume (from 0.3 to $0.8 \mathrm{~nm}^{3}$ ). The selectivities for ethane and propene were higher than 
Table 3 Zeolites with 10- and 12-Membered Rings Used for $n$-Pentane Cracking

\begin{tabular}{clcccc}
\hline Catalyst number & Zeolite & Pore dimensionality & $\boldsymbol{d}_{\max }{ }^{\mathrm{a})}[\mathrm{nm}]$ & $\boldsymbol{D}_{\mathbf{i}}^{\mathrm{b})}[\mathrm{nm}]$ & Cavity volume $\left[\mathrm{nm}^{3}\right]$ \\
\hline 10-membered ring & & & & \\
1 & & & & & \\
2 & SAPO-41 & 1 & 0.501 & 0.537 & $8.1 \times 10^{-2}$ \\
3 & SAPO-11 & 1 & 0.457 & 0.558 & $9.1 \times 10^{-2}$ \\
4 & ZSM-22 & 1 & 0.505 & 0.565 & $9.4 \times 10^{-2}$ \\
5 & ZSM-23 & 1 & 0.501 & 0.613 & $1.2 \times 10^{-1}$ \\
6 & ZSM-5(69) & 3 & 0.464 & 0.630 & $1.3 \times 10^{-1}$ \\
7 & Nu-87 & 2 & 0.501 & 0.698 & $1.8 \times 10^{-1}$ \\
8 & ZSM-11 & 3 & 0.513 & 0.766 & $2.4 \times 10^{-1}$ \\
12 -membered ring ${ }^{\text {c) }}$ & MCM-22 & 2 & 0.486 & 0.963 & $4.7 \times 10^{-1}$ \\
9 & & & & & \\
10 & SAPO-31 & 1 & 0.543 & 0.568 & $9.6 \times 10^{-2}$ \\
11 & ZSM-12 & 1 & 0.562 & 0.602 & $1.1 \times 10^{-1}$ \\
12 & MCM-68 & 3 & 0.494 & 0.703 & $1.8 \times 10^{-1}$ \\
13 & CIT-1 & 3 & 0.554 & 0.739 & $2.1 \times 10^{-1}$ \\
14 & SAPO-5 & 1 & 0.736 & 0.824 & $2.9 \times 10^{-1}$ \\
\hline
\end{tabular}

a) Maximum free sphere diameter.

b) Maximum included sphere diameter.

c) Largest pore structure in the zeolite.

the selectivities for other product pairs. On the other hand, the selectivities for ethane and propene (produced via Eq. (2)) simultaneously increased with volume of the zeolite cavity less than $0.3 \mathrm{~nm}^{3}$ (Fig. 8), and the selectivities for hydrogen and pentane, methane and butenes, and propane and ethene decreased slightly (data provided in Ref. 30)). These variations were smaller than those of the selectivities for ethane and propene. These results show that the selectivities for the primary reactions expressed by reactions (1)-(4) in Fig. 8 depend on the cavity volume of the zeolite, and the primary reaction (2) in Fig. 8 is most strongly influenced by the volume of the zeolite cavity.

The volume of the pentyl carbonium ions was calculated to be about $0.12 \mathrm{~nm}^{3}$. For a cavity volume of around $0.12 \mathrm{~nm}^{3}$, the selectivities for ethane and propene were high using zeolites with both 10- and 12-membered rings (Fig. 9). If the volume of the zeolite cavity was almost same as that of the carbonium ions, the interaction of the carbonium ions with the wall of the zeolite cavity was probably optimized. The increased selectivities for ethane and propene imply that optimization of the interaction, stabilizes a specific reaction intermediate (the carbonium ions in reaction (2) in Fig. 8) to a greater extent in the zeolite cavity than other reaction intermediates (carbonium ions in reactions (1), (3), and (4) in Fig. 8).

The selectivities for alkenes, hydrogen, and alkanes in the primary reactions (i.e., the protolysis reactions) for $n$-pentane cracking were not correlated with the turn over frequencies (TOFs) of the zeolites with both 10 -membered rings and 12 -membered rings ${ }^{30}$. The TOF is a measure of the acid strength. This result indicates that the primary product selectivities did not depend on the acid strength, so that factors other than the

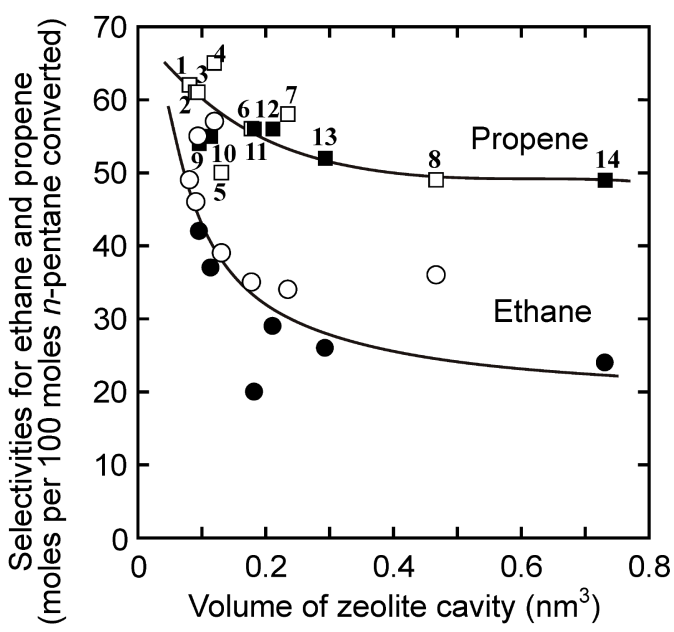

$\bigcirc$ : Ethane, 10-membered ring zeolite; : ethane, 10-membered ring zeolite; $\square$ : propene, 10 -membered ring zeolite; $\square$ : propene, 12-membered ring zeolite. Numbers shown in the figure correspond to the catalyst numbers in Table 3 .

Reaction conditions: reaction temperature $823 \mathrm{~K}$; $n$-pentane pressure $10.1 \mathrm{kPa}$.

Fig. 9 Selectivities for Ethane and Propene in the Primary Reaction Plotted against the Cavity Volume of the Zeolite

acid strength determine the primary product selectivities. Furthermore, the primary product selectivities were not determined by the entrance pore diameter of the zeolite $\left(d_{\max }\right)^{32)}$.

\section{Summary}

Analysis of the product selectivity suggested that alkane conversion proceeded in the cavity of alkane monooygenases and proton-exchanged zeolites. We 
propose that product selectivity is optimized if the molecular volume of the reacting molecules or reaction intermediates is almost identical to the volume of the cavity in which the catalytic reactions proceed. This concept is common to zeolites and enzymes, implying that the concept can be generally applied to catalysts with a cavity structure. Furthermore, this concept can also be applied to the conversion of alkanes as well as other molecules where only weak intramolecular forces are operative, such as in the conversion of alkenes. We previously reported that the cavity volume is a determining factor of the selectivity for propene in olefin conversion catalyzed by proton-exchanged zeolites ${ }^{33)}$. Based on the present concept of product selectivity expression the optimum catalyst for a requisite reaction can be selected using the volumes of the catalyst cavity and the reacting molecule as indicators. However, the underlying reason controlling the high molecular recognition achieved by matching of the volume of the cavity with the volume of the reacting molecules or reaction intermediate remains unknown. If this mechanism can be elucidated, high selectivity of the catalyst can be achieved for any required product.

The proposed concept is applicable to zeolites and enzymes as well as other catalysts with a cavity structure. In recent years, synthetic techniques for developing new materials containing cavity structures such as supramolecular compounds, metal-organic frameworks (MOF), and recombinant proteins and their crystals has advanced remarkably. Also, the speed of computer calculations and quantum chemistry calculations has developed significantly, allowing rapid and precise calculations for large and complex molecules. Combining these molecular construction techniques and quantum chemical calculation methods with the present concept may provide a route for establishing catalysts that exhibit high selectivity in catalytic reactions.

\section{Acknowledgment}

This work was supported by JSPS KAKENHI Grant Number 23760739, 25630363.

\section{References}

1) Scarso, A., Trembleau, L., Rebek Jr., J., J. Am. Chem. Soc., 126, 13512 (2004).

2) Mecozzi, S., Rebek Jr., J., Chem. Eur. J., 4, 1016 (1998).

3a) Li, Z., Chang, D., Curr. Org. Chem., 8, 1647 (2004).

3b) Funhoff, E. G., Van Beilen, J. B., Biocatal. Biotransform., 25, 186 (2007).

4a) Liu, R., Loll, P. J., Eckenhoff, R. G., FASEB J., 19, 567 (2005).

4b) Zürcher, M., Gottschalk, T., Meyer, S., Bur, D., Diederich, F., ChemMedChem, 3, 237 (2008).

5a) Miyaji, A., Miyoshi, T., Motokura, K., Baba, T., Biotech. Lett., 33, 2241 (2011).

5b) Miyaji, A., Method. Enzymol., 495, 211 (2011).

6) Miyaji, A., Miyoshi, T., Motokura, K., Baba, T., Org. Biomol. Chem., 13, 8261 (2015). 7a) Balasubramanian, R., Smith, S. M., Rawat, S., Yatsunyk, L. A., Stemmier, T. L., Rosenzweig, A. C., Nature, 465, 115 (2010).

7b) Himes, R. A., Barnese, K., Karlin, K. D., Angew. Chem., Int. Ed., 49, 6714 (2010).

7c) Smith, S. M., Balasubramanian, R., Rosenzweig, A. C., Methods Enzymol., 495, 195 (2011).

8) Culpepper, M. A., Cutsail, G. E., Hoffman, B. M., Rosenzweig, A. C., J. Am. Chem. Soc., 134, 7640 (2012).

9a) Martinho, M., Choi, D. W., DiSpirito, A. A., Antholine, W. E., Semrau, J. D., Muenck, E., J. Am. Chem. Soc., 129, 15783 (2007).

9b) Liew, E. F., Tong, D., Coleman, N. V., Holmes, A. J., Microbiology, 160, 1267 (2014).

10) Chan, S. I., Yu, S. S., Acc. Chem. Res., 41, 969 (2008).

11) Balasubramanian, R., Rosenzweig, A. C., Acc. Chem. Res., 40, 573 (2007).

12a) Shiota, Y., Yoshizawa, K., Inorg. Chem., 48, 838 (2009).

12b) Yoshizawa, K., "Copper-oxygen Chemistry," eds. by Karlin, K. D., Itoh, S., John Wiley \& Sons, Inc., Hoboken, N. J., USA (2011), p. 197.

12c) Himes, R. A., Karlin, K. D., Curr. Opin. Chem. Biol., 13, 119 (2009).

13a) Wilkinson, B., Zhu, M., Priestley, N. D., Nguyen, H.-H. T., Morimoto, H., Williams, P. G., Chan, S. I., Floss, H. G., J. Am. Chem. Soc., 118, 921 (1996).

13b) Yu, S. S.-F., Wu, L.-Y., Chen, K. H.-C., Luo, W.-I., Huang, D.S., Chan, S. I., J. Biol. Chem., 278, 40658 (2003).

14) Miyaji, A., Suzuki, M., Baba, T., Kamachi, T., Okura, I., J. Mol. Catal. B, 57, 211 (2009).

15a) Elliot, S. J., Zhu, M., Tso, L., Nguyen, H.-H. T., Yip, J. H.-K., Chan, S. I., J. Am. Chem. Soc., 119, 9949 (1997).

15b) Burrows, K. J., Cornish, A., Scott, D., Higgins, I. J., J. Gen. Microbiol., 130, 3327 (1984).

16a) Lieberman, L. L., Rosenzweig, A. C., Nature, 434, 177 (2005).

16b) Hakemian, A. S., Kondapalli, K. C., Telser, J., Hzoffman, B. M., Stemmler, T. L., Rosenzweig, A. C., Biochemistry, 47, 6793 (2008).

17) Bédard, C., Knowles, R., Microbiol. Rev., 53, 68 (1989).

18) Hyman, M. R., Wood, P. M., Biochem. J., 212, 31 (1983).

19a) Hyman, M. R., Murton, I. B., Arp, D. J., Appl. Environ. Microbiol., 54, 3187 (1988).

19b) Keener, W. K., Arp, D. J., Appl. Environ. Microbiol., 60, 1914 (1994).

20) Weijers, C. A. G. M., van Ginkel, C. G., de Bont, J. A. M., Enzyme Microbial. Tech., 10, 214 (1988).

21) Holmes, A. J., Costello, A., Lidstrom, M. E., Murrell, J. C., FEMS Microbiol. Lett., 132, 203 (1995).

22) Bondi, A., J. Phys. Chem., 68, 441 (1964).

23) Harpaz, Y., Gerstein, M., Chothia, C., Structure, 2, 641 (1994).

24) Ensign, S. A., Hyman, M. R., Arp, D. J., J. Bacteriol., 175, 1971 (1993).

25) Cook, B. R., Reinert, T. J., Suslick, K. S., J. Am. Chem. Soc., 108, 7281 (1986).

26) Kopp, D. A., Lippard, S. J., Curr. Opin. Biotechnol., 6, 568 (2002).

27) Sazinsky, M. H., Lippard, S. J., J. Am. Chem. Soc., 127, 5814 (2005).

28) Koshland, D., Proc. Natl. Acad. Sci. USA, 44, 98 (1958).

29a) Haag, W. O., Dessau, R. M., Proc. 8th Int. Congr. Catal., Verlag Chemie, Weinheim (1984), vol. II, p. 305.

29b) Ono, Y., Kanae, K., J. Chem. Soc., Faraday Trans., 87, 663 (1991).

29c) Krannila, H., Haag, W. O., Gates, B. C., J. Catal., 135, 115 (1992).

29d) Abbot, J., Wojciechowski, B., J. Catal., 115, 1 (1989).

29e) Shertukde, P. V., Marcelin, G., Sili, G. A., Hall, W. K., J. Catal., 136, 446 (1992). 
29f) Nabeshuber, T. F., Vinek, H., Lercher, J. A., J. Catal., 157, 388 (1995).

30) Miyaji, A., Iwase, Y., Nishitoba, T., Long, N. Q., Motokura, K., Baba, T., Phys. Chem. Chem. Phys., 17, 5014 (2015).

31) Treacy, M. M. J., Foster, M. D., Micropo. Mesopor. Mater, 118, 106 (2009)

32) Foster, M. D., Rivin, I., Treacy, M. M. J., Delgado Friedrichs, O., Micropor. Mesopor. Mater, 90, 32 (2006). 33a) Miyaji, A., Sakamoto, Y., Iwase, Y., Yashima, T., Koide, R., Motokura, K., Baba, T., J. Catal., 302, 101 (2013).

33b) Iwase, Y., Sakamoto, S., Shiga, A., Miyaji, A., Motokura, K., Koyama, T., Baba, T., J. Phys. Chem. C, 116, 5182 (2012).

33c) Koyama, T., Hayashi, Y., Horie, H., Kawauchi, S., Matsumoto, A., Iwase, Y., Sakamoto, Y., Miyaji, A., Motokura, K., Baba, T., Phys. Chem. Chem. Phys., 12, 2541 (2010).

要旨

\title{
酵素およびゼオライトの空洞内でのアルカン転化反応における生成物選択性 一空洞容積が生成物への選択性に及ぼす影響—
}

\author{
宮地 輝光
}

東京工業大学大学院総合理工学研究科化学環境学専攻, 226-8502 横浜市緑区長津田町4259-G1-14

アルカンモノオキシゲナーゼやプロトン交換ゼオライトで は，これら触媒分子内に空洞構造を有しており，この空洞内で アルカン転化反応が進行する。本研究では, キャビティ容積お よび反応分子の体積が触媒反応の生成物選択性に及ぼす影響を 明らかにするため, アルカンモノオキシゲナーゼによる直鎖ア ルカンからアルコール位置・立体異性体への選択性，およびプ ロトン交換ゼオライトによる $n$-ペンタン分解反応におけるア
ルカンおよびアルケンへの選択性を明らかにした。アルカンモ ノオキシゲナーゼにおける $n$-アルカンから 2-ヒドロキシアルカ ン立体異性体への選択性, およびプロトン交換ゼオライトによ るn-ペンタンからエタンとプロペンへの選択性は, それら触 媒の空洞容積に依存した。これらの結果に基づき, 反応分子ま たは反応中間体の大きさが, 触媒反応が進行する空洞の容積と 一致したとき生成物への選択性が発現されることを提案する。 